\title{
Jan Lechoń do Stefana Żeromskiego. Korespondencja ze zbiorów Moniki Żeromskiej
}

Roman Loth 


\title{
Jan Lechoń do Stefana Żeromskiego. Korespondencja ze zbiorów Moniki Żeromskiej
}

\author{
Opracował Roman Loth
}

T an Lechoń, dwudziestoletni wówczas poeta, poznał Stefana Żeromskiego latem 1919 roku

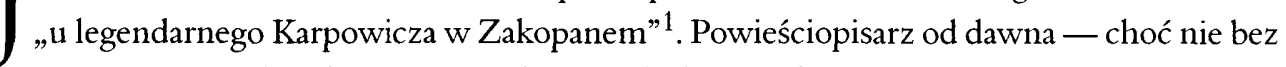
przerw - mieszkał pod Tatrami. Lechoń spędzal tam urlop. Na co dzień odbywal wlaśnie swą ochotniczą służbę wojskową jako szeregowiec Kompanii Sztabowej Naczelnego Dowództwa („siedziałem bowiem wtedy jako kancelaryjna oferma na placu Saskim” - napisze o sobie później ${ }^{2}$ ), doglądając jednocześnie redaktorskim okiem kolejnych zeszytów „Pro arte”. „Nie pamiętam już tego dobrze, ale zdaje mi się, że przedstawiła mnie państwu Żeromskim - pani Orkanowa" - pisał po latach w swoim wspomnieniu ${ }^{3}$. Stosunki szybko się zacieśnity:

Kiedy wyjeżdżałem z Zakopanego, było postanowione i przyrzeczone, że ta znajomość będzie dalej praktykowana w Warszawie, gdzie państwo Żeromscy mieli powrócić na stałe po latach przymusowego pobytu poza Królestwem i że zostanę wówczas powiadomiony o ich powrocie ${ }^{4}$.

Zachowanym świadectwem owego praktykowania nawiązanych kontaktów jest 15 publikowanych tu listów, zachowanych w rodzinnym archiwum pozostałym po Stefanie Żeromskim w jego willi w Konstancinie, a udostępnionych mi dzięki łaskawej zgodzie córki pisarza, p. Moniki Żeromskiej ${ }^{5}$.

\footnotetext{
' J. Lechoń, Żeromski. Bankiet pod Bachusem, ,Wiadomości” (Londyn) 1951, nr 16 (22 IV), s. 2.

: Idem, Motyw Krakowa, „Gazeta Polska” 1936, nr 70 (10 III).

${ }^{3}$ Idem, Żeromski. Bankiet pod Bachusem, zob. przypis 1.

+ Ibidem.

${ }^{5}$ Z listów Żeromskiego do Lechonia znane są dwa: $z$ Warszawy (22 XII 1921) i z Gardone (10 IV 1924). Oba wydał Jerzy Kądziela w: Nieznane listy Żeromskiego, „Pamiętnik Literacki” 1956, z. 3, s. 244-246.
} 
Zespół ten obejmuje okres od grudnia 1919 do września 1925 roku. Dla młodego poet są to lata największych triumfów pisarskich: w styczniu 1920 roku wychodzi spod pras Karmazynowy poemat, jesienią 1924 Srebrne i czarne — dwa tomiki, które zapisały się w dziejacl polskiej poezji i utrwaliły ostatecznie pozycję Lechonia w opinii krytyków i czytelników. Al jest to również czas jego dolegliwych kłopotów zdrowotnych. Długimi nawrotami rozwij się choroba nerwowa Lechonia. Zapadł na nią jako chłopiec jedenastoletni, wielokrotni podejmowane kuracje skutkowały krótkotrwale. Poeta szukał odpoczynku w Zakopanem w trakcie leczenia przebywał w Rabce. W lutym 1920 roku ojciec Lechonia, Dionizy Włady sław Serafinowicz, donosi bratu w Sieradzu, iż „stan zdrowia Leszka zupełnie się nie popra wia, pomimo że to trwa już 2 miesiące" ${ }^{\text {. }}$. Korzystając $z$ wyjazdu Żeromskiego nad morze, d Orłowa, młody poeta podąża za nim i w jego towarzystwie spędza nadmorskie lato niespo kojnego roku 1920. Wobec zbliżającej się ofensywy bolszewickiej i Żeromski, i Lechor powracają do Warszawy. Matka poety, Maria Serafinowiczowa, dziękuje pisarzowi listen z dnia 20 lipca 1920 roku:

Szanowny Panie! Wyrazy szczerej podzięki i serdecznej wdzięczności przesylam w moim i męża imieniu za życzliwą opiekę nad naszym Lechem oraz przepraszam najmocniej za cały kłopot, jaki sprawiał Szanownemu Panu swoją osobą. Powrócił bardzo zmęczony i podniecony, wierzę jednak, że w naszym zaciszu ${ }^{7}$, które robi wrażenie zakątka wiejskiego, w otoczeniu osób, z którymi prawie nigdy się nie rozstawał na czas dłuższy, prędko wróci do równowagi duchowej $(\ldots)^{8}$.

Nadzieje, niestety, niespełnione. Wkrótce poeta zostaje odwieziony do kliniki neurologicznej Jana Piltza w Krakowie, gdzie pozostaje przez sierpień.

Wątek zdrowotny kilkakrotnie pojawia się w tym zbiorze listów. Na przedwiośniu 1921 roku Lechoń w wyniku depresji psychicznej podejmuje pierwszą próbę samobójstwa. Z trudem odratowany, znowu zostaje skierowany do krakowskiej kliniki Piltza (skąd pisze obszerny list do Żeromskiego). Tym razem pobyt w klinice jest dłuższy, trwa kilka miesięcy, poeta kuruje się również w Rabce i Zakopanem; do domu wraca w połowie września. Po raz trzeci nawrót choroby zmusza go do kuracji w Krakowie w grudniu 1922 roku:

Nazajutrz po zabójstwie Narutowicza pojechałem do sanatorium do Krakowa, bom dostał ciężkiego szoku patrząc, jak wynosili zwłoki z Zachęty9.

${ }^{6}$ Cyt. za: J. A. Kosiński, Album rodzinne Jana Lechonia, Warszawa 1993, s. 176.

${ }^{7}$ Serafinowiczowie mieszkali wówczas przy ulicy Przyrynek 4, na Nowym Mieście, przy kościele Najświętszej Marii Panny.

${ }^{8}$ List $w$ archiwum Żeromskiego w Konstancinie.

9 J. Lechoń, Dziennik, t. 3, Warszawa 1993, s. 97. 
Jest to znów pobyt kilkumiesięczny, trwający od 17 grudnia 1922 roku do maja roku następnego, zaświadczony w tym zbiorze listem oznaczonym numerem 10. „Przyboczna choroba" - jak ją sam określa - towarzyszy mu przez całe życie, z różnym nasileniem; w ostatnich miesiącach życia jest stałą udręką, która z czasem staje się nie do wytrzymania. Sam, z wlasnej woli, przecina jej pasmo samobójczym skokiem z nowojorskiego drapacza chmur.

„Mówilem już Panu, ile mu pięknego i dobrego zawdzięczam” — pisał poeta w drugim z zachowanych listów, z dnia 25 stycznia 1920 roku, a więc zaledwie w parę miesięcy po zawarciu znajomości. Domyślać się można, że w tym wyznaniu chodzi raczej o moralne i artystyczne długi wobec twórczości wielkiego pisarza, aniżeli o zobowiązania natury osobistej (na które czas dopiero przyjdzie). Spod grzecznościowych i kurtuazyjnych formut korespondencyjnych wylania się jednak chwilami coś więcej, co odtąd i na zawsze charakteryzować będzie stosunek Lechonia do Żeromskiego: podziw, miłość i uwielbienie, znajdujące często wyraz patetyczny i egzaltowany. Wzajemnie, Żeromski, zawsze życzliwy młodym pisarzom, szczególnie zaś przyjazny poetom z kręgu „Skamandra”, daje wyraz swej sympatii dla Lechonia, dedykując mu w druku "na pamiątkę Orłowa” szkic Sambor $i$ Mestwin w tomie Inter arma (Warszawa 1920). Jest to dla poety dar cenny i głębokie przeżycie. Odwdzięczy mu się wkrótce emfatyczną dedykacją na drugim wydaniu Karmazynowego poematu (Warszawa 1922): „Stefanowi Żeromskiemu, najpierwszemu sercu w Ojczyźnie”. Towarzyszyć też będzie autorowi Przedwiośnia myślą i uczuciem zawsze, a niekiedy i próbą czynnej pomocy (zaświadczoną między innymi w liście 7).

Pisarskich świadectw tej fascynacji postacią i twórczością Żeromskiego jest co najmniej kilka. To przede wszystkim dwa przejmujące wiersze na śmierć pisarza: Wzrok wznosząc pod zimouym, rozgwieżdżnym stropem (1925) i B-moll (1943). W pisanej długo (choć nie napisanej) powieści Bal u senatora jeden z głównych bohaterów, Skarga, wzorowany jest na Żeromskim; cale sceny utworu (wedlug oświadczeń autora) mają swoje pierwowzory w autentycznych z nim spotkaniach. W tomie szkiców O literaturze polskiej (1942, drugie wydanie 1946) Żeromski wymieniany jest przez Lechonia wielokrotnie i zawsze stanowi najwyższą miarę postawy obywatelskiej i artyzmu pióra. W konwencji pamiętnikarskiej pojawia się w kilku wspomnieniach poświęconych mu w całości lub w części, pamięć o nim poety dokumentuje nadto blisko sto pięćdziesiąt wzmianek w Dzienniku.

$\mathrm{Na}$ znanej fotografii z pogrzebu Żeromskiego trzej młodzi poeci: Wierzyński, Lechoń i Iwaszkiewicz kroczą w kondukcie, poprzedzając trumnę pisarza. Lechoń idzie w środku, niosąc na poduszce insygnia Orderu Odrodzenia Polski. To ostatni hołd, złożony osobiście pisarzowi. Według własnej relacji ${ }^{10}$ Lechoń mial przemawiać nad trumną Żeromskiego w imieniu młodej literatury, co uniemożliwily zakulisowe intrygi.

${ }^{10}$ Ibidem, t. 1, Warszawa 1992, s. 507. 
Pani Monika Żeromska udzieliła mi wielu informacji biograficznych do komentarza co notuję $z$ wdzięcznością.

7 września 2002 r.

Roman Lot

1.

[Warszawa, 24 XII 1919

Serdeczne i najlepsze życzenia przesylając dla obojga Państwa - proszę bardzo o wrę. czenie pannie Monice ${ }^{11}$ perwersyjnej Murzynki od nieznanego wielbiciela

24/XII 19.

Leszka Serafinowicz:

Zlożony pionowo na pół arkusz białego, cienkiego papieru listowego w linię. Format tak uzyskanej kar ty $213 \times 128 \mathrm{~mm}$. Tekst tylko na s. 1, czarnym atramentem, czytelnie.

2.

niedziela, 25/I 20

[Warszawa, 25 I 1920.

\section{Szanowny i Bardzo Drogi Panie!}

Jestem przybity do łóźka i choć szczerze pragnąłbym, nie będę mógł osobiście pożegnac $\mathrm{Pana}^{12}$ - muszę poprzestać na pożegnaniu - najserdeczniejszym, ale listownym.

Proszę przyjąć ode mnie moje wiersze ${ }^{13}$ z najszczerszymi i najlepszymi wyrazami mówilem już kiedyś Panu, ile mu pięknego i dobrego zawdzięczam.

Może będzie Pan taki dobry i spełni kaprys chorego: prositem kiedyś Panią i mam od Niej obiecaną Pana fotografię; bardzo proszę, aby użył Pan swej protekcji dla wydostania tej fotografii i łaskawego przesłania mi jej — adres mój Przyrynek 4 (Nowe Miasto, koło kościoła N. M. Panny) - albo blizej: redakcja „Skamandra”, Zlota 8 m. 5.

Jeszcze raz żegnam serdecznie Pana, rączki pięknie całując Pani i pozdrawiając ślicznie infantkę. Za prośbę mą przepraszam, za jej spełnienie z góry wiele razy dziękuję

bardzo oddany

Leszek Serafinowicz

Arkusz wytwornego, czerpanego, żeberkowanego bialego papieru listowego o szarpanych brzegach, ze znakiem wodnym. Złożony na pół. Format tak utworzonej karty 150 x ok. $160 \mathrm{~mm}$. Tekst tylko na s. 1, czarnym atramentem: czytelnie.

"Sześcioletniej wówczas córce pisarza (w dalszych listach określana również jako „panna Mumcia").

12 Nie udało się ustalić, dokąd Żeromski wyjeżdżat.

${ }^{13}$ Karmazynowy poemat, Warszawa 1920. 


\section{3.}

Szanowny i Bardzo Drogi Panie!

[Warszawa, koniec IV lub początek V 1920]

Pewna młoda panienka ${ }^{14}$, moja znajoma, bardzo za moim pośrednictwem prosi Pana o położenie swego autografu na załączonym tomie Popiołów.

Myślę, że nie raz był Pan już narażony na takie fatygi, z góry więc serdecznie w swoim i tej młodej osoby imieniu Panu dziękuję, a za kłopot przepraszam.

Nie wiem, czy przed wyjazdem Państwa będę mógł Im złożyć moje uszanowanie, co sobie poczytuję za mily obowiązek; jak na złość znowu w ostatnich dniach nieco gorzej się czuję i ledwo na parę chwil wydalam się z domu.

Na wszelki więc wypadek żegnam najpiękniej Państwa, myślę, że nie na długo. Byłbym Panu nieskończenie wdzięczny, gdyby po przyjeździe do Adlershorst ${ }^{15}$ napisał mi Pan laskawie parę słów - czy są mieszkania, jakie i ile życie kosztuje. Jeszcze raz przepraszam za kłopot, łączę ucałowania rączek dla Pani, dla Pana wyrazy najgłębszego oddania i szacunku, z jakimi pozostaję

Leszek Serafinowicz

PS. Popioty może będzie Pan tak dobry i zostawi u pp. Mortkowiczów ${ }^{16}$.

Szaroniebieski kartonik formatu $92 \times 108 \mathrm{~mm}$. Złożony poziomo na pól. Tekst czarnym atramentem, dość czytelnie (choć z kreśleniami), obustronnie.

Datowanie: list pisany tuż przed wyjazdem Żeromskiego z Warszawy do Orłowa, co nastąpiło w maju 1920 roku.

\section{4.}

[Warszawa, 2 IX (?) 1920]

Szanowny i Bardzo Drogi Panie!

Ponieważ dzisiaj, zdaje się, są Imieniny Pana ${ }^{17}$ (jeżeli się pomyliłem — nic nie szkodzi) - przesyłam Panu najlepsze i bardzo serdeczne życzenia, o których był Pan chyba zawsze przekonany.

Moja nieznośna choroba nie pozwala mi złożyć ich osobiście — tym silniej chciałbym tu zaznaczyć, jak są szczere i gorące.

Myślę często, co u Państwa słychać, $z$ trudem wyobrażając sobie np. jak pan wygląda w mundurze ${ }^{18}$, ciekaw też jestem, jaką „służbę pozafrontową" pełni panna Mumcia (czy Mruczek jest w Warszawie — a jeśli tak — czy mruczy?).

${ }^{34}$ Nie udało się zidentyfikować osoby. Może Wanda Serkowska, ówczesna sympatia Lechonia?

${ }^{15}$ Nazwa pensjonatu, w którym mieszkał Żeromski w Orłowie, brzmiała „Adlerhof” (informacja p. Moniki Żeromskiej).

${ }^{16}$ Jakub Mortkowicz, wydawca i przyjaciel Żeromskiego, i jego żona Janina.

${ }_{17}$ Żeromski obchodził imieniny 2 września. Dzień św. Stefana przypada jednak w kalendarzu kilkakrotnie, datowanie listu nie jest więc pewne.

${ }^{18}$ Wobec postępów ofensywy bolszewickiej latem 1920 roku, zostala utworzona Armia Ochotnicza pod 
Jeszcze raz życzę Panu wszystkiego najlepszego, a za doznane od Niego jeszcze ra: najmocniej dziękuję, Pani przesyłam ucałowania rączek, jak również p. Mumci (na papierzı chyba wolno)

bardzo, bardzo oddan:

Leszek Serafinowic:

Arkusz wytwornego, grubego, białego papieru listowego o szarpanych brzegach, formatu 206 x ok. $157 \mathrm{~mm}$ Tekst jednostronnie, czarnym atramentem, czytelnie.

\section{5.}

[Warszawa, wrzesień 1920

\section{Bardzo Drogi Panie!}

Z serdecznym wzruszeniem przeczytałem na prześlicznej Pana nowelce tak laskaw: i kochaną dedykację ${ }^{19}$.

Nie jestem jeszcze na tyle „w formie”, aby móc osobiście Panu najserdeczniej podziękować, co jest moim gorącym pragnieniem. Czynię to chwilowo listownie - proszę mnie nic posądzać, że przez to odrobinę choćby mniej serdecznie, moje niedolęstwo teraz dopierc naprawdę przeklinam.

Nie ma Pan pojęcia, ile mi Pan dobra wyświadczył - dziękuję Panu bardzo, bardzc gorąco.

Oddany cały

Leszek Serafinowicz

PS. Pani ucałowania rączek i (jeśli pozwoli) pannie Mumci.

List na blankiecie z nadrukiem: SOCIÉTÉ ÉDITRICE À VARSOVIE [...], Varsovie, rue Mazowiecka 12 [...] Biały, cienki papier ze znakiem wodnym, formatu $278 \times 217 \mathrm{~mm}$. Czarny atrament, pismo wyráne, jednostronnie Jedno skreślenie, zamazane nieomal do nieczytelności.

dowództwem gen. Józefa Hallera. Dnia 7 lipca 1920 roku powołano II Oddział Generalnego Inspektoratu tej armii, z zadaniem prowadzenia pracy propagandowo-kulturalnej. Kierownictwo referatu drugiego, obejmującego literaturę, publicystykę oraz prasę krajową i zagraniczną, powierzono Żeromskiemu. Oddział II zakończył działalność w październiku 1920 roku. Żeromski — według informacji p. Moniki Żeromskiej munduru nie nosil.

${ }^{19}$ Chodzi o drukowaną dedykację szkicu Sambor i Mestwin, brzmiącą: „Leszkowi Serafinowiczowi na pamiątkę Orlowa”. Szkic ten ukazal się w tomiku Żeromskiego Inter arma, wydanym w Warszawie we wrześniu 1920 roku. Por. uwagi we wstępie. 
6.

[Kraków, 1921, koniec marca?]

Szanowny i Bardzo Drogi Panie! Już od dawna się zbieram, aby chociaż parę słów do Pana napisać, przypomnieć się Jego pamięci i o wiadomość o[d] Państwa poprosić - ale tak mi pisanie $z$ trudem przychodzi i tak trudno $z$ mego życia tutaj wycisnąć refleksji i wrażeń na jaki taki list, że dopiero dzisiaj piszę.

Zamek, w którym mieszkam ${ }^{20}$, posiada calą hierarchię mieszkańców, od rekonwalescentów i leniuchów począwszy, skończywszy na rasowych wariatach — ja należę chwilowo do pośredniej kategorii - alkoholików, morfinistów i w ogóle ludzi niepewnych — zagadka więc mej przyszłości streszcza się w pytaniu, czy będę awansowal, czy też mnie zdegraduia. Brakuje mi cokolwiek pogody ducha do tego, aby czuć się jak na najlepszej komedii w towarzystwie kolegów-pijaków - teoretycznie jednak są to najpocieszniejsi ludzie pod słońcem, a mój pawilon jest kopalnią obserwacji. — Poza tym jestem całkiem od świata odcięty - oprócz moich pijaków, lekarzy i co pewien czas Boya ${ }^{21}$ nikogo nie widuję wychodzę czasem na spacer - ale Kraków tak jest zapchany kościołami i księżmi, że moje świeckie myśli czują się bardzo nieswojo. Myślę też ciągle o Warszawie i pozwoliłem sobie przez pannę Hanię Mortkowiczównęe22 zapytywać o Państwa - wiem, że czuł się Pan niedobrze w Zakopanem ${ }^{23}$ i tym niecierpliwiej czekatem na wiadomości o zdrowiu Pana okazuje się, że i Konstancin jest „stacją klimatyczną”. Dowiedziałem się też od Boya, że jest Pan jednym $z$ kandydatów do nagrody Nobla ${ }^{24}$ - musi ją Pan otrzymać koniecznie już nie tylko dlatego, że nie byłoby inaczej sprawiedliwości na świecie, ale i dlatego, że będzie to świętem dla tylu oddanych Panu ludzi; tutaj, w Krakowie, wszyscy są pod wrażeniem tej wiadomości. Podobno sprawa „Akademii” 25 bardzo ostatnio posunęla się naprzód; myślę, że zały szereg wystąpień i incydentów z ostatnich czasów wykazał naglącą potrzebę jakiegoś autorytetu w opiniach i życiu literackim; jeszcze dotąd złość mnie trzęsie, gdy pomyślę っ Pieńkowskim ${ }^{26}$.

:0 Klinika neurologiczno-psychiatryczna Uniwersytetu Jagiellońskiego, kierowana przez prof. Jana Piltza. Według ustaleń Józefa Adama Kosińskiego Lechoń przebywał w roku 1921 na kuracji w Krakowie od 16 marca.

"1 Tadeusz Żeleński (Boy), wówczas jeszcze mieszkający w Krakowie.

?2 Piętnastoletnia wówczas córka Jakuba i Janiny Mortkowiczów, znana później jako pisarka Hanna Mortkowicz-Olczakowa.

${ }^{23} \mathrm{Na}$ początku roku 1921 Żeromski był w Zakopanem, skąd 24 lutego wyjechal do Konstancina, do zakupionej w lipcu roku ubiegłego willi.

24 Projekt wysunięcia kandydatury Żeromskiego do literackiej nagrody Nobla pojawił się w roku 1920. Ponowne starania podjęło poselstwo polskie w Sztokholmie w początku roku 1921 i w końcu stycznia otrzymało konieczny do dalszych działań formalny wniosek w tej sprawie od Polskiej Akademii Umiejętności w Krakowie.

${ }_{25}$ Postulowanej przez Żeromskiego Akademii Literatury Polskiej. (Por. jego Projekt Akademii Literatury Polskiej, Warszawa-Kraków 1918).

26 Stanisław Pieńkowski, krytyk związany z narodową demokracją, współpracownik „Gazety Warszawskiej”, autor napaści prasowych na Zeromskiego. Tu chodzi zapewne o najświeższe jego wystąpienie: recenzję Biatej rękawiczki (Teatr Polski: „Biała rękauviczka” St. Żeromskiego, „Gazeta Warszawska” 1921, nr 69/70 z 11/12 III), niesprawiedliwą i demagogiczna. (Pieńkowski konkludowal: „Wbrew woli i wiedzy swej, Żeromski napisał 
Niech mi Pan daruje, że ten list, który miał być tylko paroma słowami oddania i przypo mnieniem się, stał się, co konstatuję z przestrachem - większą arią liryczną; gdyby Par znalazł chwilkę czasu na doniesienie mi, co słychać u Państwa, jak zdrowie Pana i Mumci czy wyjadą gdzie Państwo - byłbym Mu obowiązany nieskończenie.

I jeszcze jedna prośba - którą zanoszę w poczuciu pewnej bezkarności jako, bądź cc bądź, chory: przymówiłem się w swoim czasie o fotografię Pana ${ }^{27}$, której nie posiadał Par wtenczas. Jeżeli ma ją Pan teraz i zechce mi ją przesłać, wyświadczy mi Pan wielką radość.

Pani i Mumci rączki caluję; Pana za nudziarstwo przepraszam i pozostaję z szacunkien i największym oddaniem

Leszek Serafinowic:

[Pionowo, wzdluż lewego marginesu, na karcie 2 dopisek z adresem zwrotnym:]

Kraków, Kopernika 46, Klinika prof. Piltza.

Arkusz cienkiego, białego papieru listowego, złożony na pól. Format tak powstałej karty 144 x $168 \mathrm{~mm}$. Teks na s. 1-3. Czarny atrament, pismo niezbyt czytelne, nieco skreśleń, niektóre zakreskowane po cenzorsku, di nieczytelności.

7.

Bardzo Drogi i Szanowny Panie!

Warszawa, dnia 6-go [X? XI?] $1921 \mathrm{r}$

Wczoraj nie mogłem wywiązać się z przyrzeczenia — gdyż potrzebnych informacji niє dostarczono mi, obiecując zrobić to dzisiaj. Dzisiaj dowiedziałem się, niestety, tyle tylko, ż sprawa opróżnienia mieszkania ${ }^{28}$ znajduje się na dobrej drodze i powinna być w tych dniack zalatwiona.

Nie ma Pan pojęcia, jak serdecznie i głęboko jest mi przykro, że nie mogę, jak tego chciałbym: przyspieszyć całej sprawy; rozumiem, ile to wszystko kosztuje Pana niewygód i nerwów.

Mieszkanie, o którym mowa - mieści się na Lesznie w domu nr 98 - jest to bardzc daleko - myślę jednak, że znaleźć coś innego byłoby bardzo trudno.

Jeszcze raz bardzo Pana przepraszam; jestem bardzo zmartwiony, że jeszcze jakiś czas sprawa potrwa - robię, co mogę, aby za parę dni ją załatwić.

Wyrazy glębokiego szacunku i oddania łączę

Jan Lechoń

List na papierze firmowym $z$ nadrukiem - w lewym górnym rogu: TOWARZYSTWO WYDAWNICZF / IGNIS / WARSZAWA [...]; w prawym: Warszawa [...], Krak-Przedm. [Krakowskie Przedmieście] 9. Papieı

utwór [ ...] dla bandytów i paskarzy. Oni wlaśnie będą się rozkoszowali tym «swoim» światem, odmalowanym bez satyry na nich, ale $z$ calą dla nich sympatią").

27 Por. list 2.

${ }^{28}$ Jesienią 1921 roku Żeromski, chory, zostal przewieziony z Konstancina do szpitala w Warszawie. Pozostal na czas pewien w stolicy. $Z$ tą decyzją wiążą się poszukiwania mieszkania, zakończone zresztą skutkiem negatywnym. Żeromscy zamieszkali wówczas na pół roku u Mortkowiczów, przy ul. Okólnik 5. 
jiałoszary, żeberkowany, cienki, w podłużną kratkę, ze znakiem wodnym. Format 278 x $216 \mathrm{~mm}$. Atrament aiebieski, tekst dość czytelny, ze skreśleniami (niektóre z nich zamazane do nieczytelności).

W dacie listu brak liczby miesiąca.

8.

Szanowny i Drogi Panie!

[Sopot, 1922 jesień]

Byłem przez parę dni w Zoppotach ${ }^{29}$; $\mathrm{z}$ dnia na dzień wybierałem się na Hel, aby zlożyć moje uszanowanie Państwu. Uniemożliwia mi to nagły wyjazd i zanim będę mógł sam powiedzieć najlepsze i najoddańsze uczucia, z jakimi pozwalam sobie ofiarować Panu moją książeczkę ${ }^{30}$, korzystam z łaskawej grzeczności młodego p. Szturma ${ }^{31}$, aby przesłać Panu egzemplarz.

Najpiękniej życzę dalszego miłego pobytu na Helu, Pani i Mumci rączki całuję, łączę wyrazy najgłębszego szacunku i oddania dla Pana

Leszek Serafinowicz

Arkusz dobrego, lekko kremowego papieru listowego ze znakiem wodnym, złożony na pól. Format tak powstałej karty 194 x $159 \mathrm{~mm}$. Tekst tylko na s. 1, czarnym atramentem, czytelnie, z jednym starannie zamazanym skreśleniem.

9.

warszawa teatr reduta ${ }^{32}$ żeromski

Kraków, 24 IV [1923]

najserdeczniejsze życzenia i powinszowania oddany lechoń

Blankiet telegraficzny z naklejonym tekstem dalekopisu. Nadany w Krakowie 24 kwietnia, odebrany tegoż dnia w Warszawie. Data roczna przy adnotacjach nadawczych nie wymieniona, przy datowniku odbiorczym zatarta do nieczytelności. Blankiet był wydrukowany w marcu 1923.

10.

\section{Szanowny i Bardzo Drogi Panie!}

Kraków, 15 maja [1]923.

Bardzo, bardzo serdecznie dziękuję Drogiemu Panu za tyle łaskawą Jego pamięć o mnie i za Turonia ${ }^{33}$ — od pierwszych chwil pobytu w Krakowie zbierałem się, aby napisać do Pana

29 Zoppot (niem.) i w spolszczeniach: Copoty, Sopoty - używane wówczas nazwy Sopotı.

${ }^{30}$ Karmazynouy poemat, wyd. 2, Warszawa 1922. Było to wydanie opatrzone drukowaną dedykacją: „Stefanowi Żeromskiemu, najpierwszemu sercu w Ojczyźnie”.

${ }^{31}$ Prawdopodobnie byl to Tadeusz Szturm de Sztrem (1893-1968), statystyk, późniejszy sekretarz Instytutu Gospodarstwa Społecznego i bliski współpracownik Stefana Starzyńskiego.

${ }^{32}$ Dnia 24 kwietnia 1923 roku w Teatrze „Reduta” w Warszawie odbyła się prapremiera Turonia Żeromskiego.

${ }^{33}$ Dramat Żeromskiego Turoń ukazal się drukiem w marcu 1923 roku. 
i o to, co się u Państwa dzieje, zapytać - ale tak mi czas zajmowały rozmaite gimnastyki kąpiele, kopanie w ogrodzie itd., że w przerwach między tym wszystkim zaledwie że mi czası starczyło na chorobę.

Ciaggle jednak czułem się dłużnikiem Pana i do dziś dnia piecze mi sumienie - egzem plarz Karmazynowego poematu, specjalnie dla Pana drukowany — powierzyłem go wyjeżdżaja jesienią z Sopotu - pewnemu mtodzieńcowi, który miał go Panu na Hel zawieźć ${ }^{34}$ przyjechawszy tamjednakjuż Pana nie zastał — później szukałem tego posłańca po Warszawi i tak z dnia na dzień odwlekało się to, aż mnie znów moja „przyboczna” choroba na dłuższ?. czas zrobiła niegrzecznym i niewdzięcznym.

Teraz odbywam kurację zamkniętą i bardzo uciążliwą, bo mi zastrzykują „baccillus coli” co wywoluje silną gorączkę - mogę więc tylko marzyć sobie o Warszawie i bezradnit wyobrażać sobie Sulkowskiego z Osterwą i Turonia z Jaraczem ${ }^{35}$ - mówiono w Krakowie, ż Osterwa ma przyjechać na gościnne występy i że będzie grał Sułkowskiego.

Tak samo „przeleżałem” Focha ${ }^{36}$, na którego przyjęcie Kraków specjalnie się wysadził w „rondlu” były kontusze i karabele na karmazynach i świniarzach [?] ${ }^{37}$, przy powozi banderia krakusów, z których niejeden jeżeli nie samego Franza Josepha, to przynajmnie Karola i Zytę ${ }^{38}$ eskortowal - hajducy miejscy na koźle - jen[erał] Szeptycki ${ }^{39}$ na czelt eskorty - do dziś dnia jeszcze „Kurierek Ilustrowany” ${ }^{40}$ wytyka Warszawie, że na raucie n: Zamku goście rzucali niedopałki na obrus, że gdyby nie policja, to by warszawscy gapit zatratowali i Focha, i Wojciechowskiego ${ }^{41}$ — słowem w Krakowie było najładniej, najporząd. niej i najbardziej się Fochowi podobało.

W porównaniu z 21 rokiem, kiedy ostatni raz byłem na dłużej w Krakowie ${ }^{42}$ - okropnic to miasto upadło i choć jeszcze mu daleko do tego, co o nim Nowaczyński pisze — al w każdym razie im się więcej wartościowych ludzi do Warszawy przenosi - tym się ważniejs: czują te „krakowskie pośmieciuchy”, z którymi, jak pisal kiedyś w białej pasji Nowaczyńsk — „żlopie redaktor Haecker lody u Bisanza i maślankę w "Teatralnej»" 43 — i prof. Sinko

\footnotetext{
${ }^{34}$ Por. list 8.

${ }^{35}$ Chodzi o warszawskie inscenizacje dramatów Żeromskiego: Sulkowski (Teatr im. W. Bogusławskiego z Juliuszem Osterwą w roli tytułowej, premiera 2 V 1923) i Turoń (por. list 9), w którym Stefan Jaracz gra: Jakuba Szelę.

${ }_{36}$ Ferdynand Foch, marszalek Francji, był z oficjalną wizytą w Polsce od 2 do 13 maja 1923 roku. W Krakowiє przebywal w dniach 11-13 maja.

${ }^{37}$ Wyraz trudno czytelny. Może: śmieciarzach?

${ }^{38}$ Chodzi o następcę Franciszka Józefa I, cesarza Karola I i jego żonę Zytę, księżniczkę Bourbon-Parma.

${ }^{39}$ Gen. Stanisław Szeptycki był wówczas inspektorem Armii Nr IV „Kraków”. Podejmował marszałka Focha w Krakowie.

to Lechoń powołuje się tu na artykuly: Zygzaki, „Ilustrowany Kurier Codzienny” 1923, nr 103 (11 V), s. 3 i Warszawskie chamstwo na Zamku Królewskim, ibidem, nr 107 (15 V), s. 4.

${ }^{41}$ Prezydent Rzeczypospolitej Polskiej, Stanisław Wojciechowski.

12 Por. list 6.

${ }^{43}$ Emil Haecker, redaktor krakowskiego dziennika Polskiej Partii Socjalistycznej „Naprzód”; Jan Bisanz; właściciel znanej restauracji i kawiarni przy pl. Szczepańskim 3 w Krakowie.
} 
który teraz referuje już nie tylko hellenizm i wielkie premiery u Słowackiego, ale i Zdobycie wierdzy Sachy Guitry, i Kobietę, która zabita, i nawet niektórym kostiumom aktorek przygania ${ }^{44}$.

Ciężko to jest napisać po wysłuchaniu Zmartwychwstania ${ }^{45}$, ale Karol Hubert Rostworowski - nie jako pisarz - ale jako przyjaciel literatury i czuły obserwator tego, co się w Polsce dzieje — jest, myślę, jednym z kilku teraz Siekierzyńskich ${ }^{46}$ — dawnego Krakowa — bardzo jest wzruszająca jego żona, córka pana Jana Popiela z Wójczy i bratanica arcybiskupa, która się obkuwa teraz wszystkich nowości w sztuce, którymi jej robi Rostworowski pilę i już do Tuwima wlącznie na wszystko się zgadza — od Tuwima zaczynają się „bezbożności” już nie tylko dla niej, ale i dla Rostworowskiego. Myślę zresztą, że trochę jest w tym racji.

Myślę często o Boyu, że zrobił i sobie, i Krakowowi wielką krzywdę, przestając być tutejszym Goethem ${ }^{47}$, do którego samotni zjeżdżają się wierni frankofile z całej Polski, tracąc nimb tajemniczości i ,splendid isolation” — przez kilka lat swej działalności krytycznej zdeprawował zresztą strasznie to miasto i teraz Sinko, który po nim w „Czasie” pisuje, też na gwałt chce być dowcipny i lekki jak piórko.

Nie wiem zupełnie, jak długo jeszcze będę tutaj siedział - takie mam uparte histerie i maniactwa - dlatego bardzo, bardzo bylbym Panu wdzięczny za parę słów choćby, co u Państwa słychać, jak Pana i panny Moniki zdrowie, czy w tym roku też się Państwo na Hel wybierają - Pannę Mumcię wyobrażam sobie teraz jako osobę, która już się pewno latek wstydzi, „o Kosturku, o Azie i o Burku” zapomniała i może już z panną Hanią Mortkowiczówną ${ }^{48}$ dysputować o literaturze - myślę jednak, że wiek mój — w zestawieniu z Jej latami daje mi prawo jeszcze jakiś czas korzystać z dawniej nabytej nazwy przyjaciela, zanim się jej będę musiał dosługiwać na nowo komplimentami i służbami należnymi dorosłej miss.

Gdyby Pan miał jakąś swą fotografię i zechciał mi ją przysłać — byłbym Panu wdzięczny nieskończenie $^{49}$ - jeszcze raz dziękuję najserdeczniej Panu i łączę wyrazy najgłębszego szacunku i serdecznego zawsze oddania, Pani pięknie rączki całuję i kłaniam się pannie Mumci

bardzo oddany i wdzięczny Leszek Serafinowicz

Kraków, Radziwiłłowska 10, dr Artwiński ${ }^{50}$, dla Lechonia.

"+ Prof. Tadeusz Sinko, filolog klasyczny, uprawiał również krytykę literacką i teatralną, m.in. jako współpracownik krakowskiego dziennika "Czas”. Wymieniony tytut: Kobieta, która zabita - to tytuł sztuki Sidneya Garricka.

${ }^{45}$ Zmartwychwstanie Karola Huberta Rostworowskiego wystawione było w Teatrze im. J. Slowackiego w Krakowie 21 kwietnia 1923 roku.

${ }^{46}$ Nawiązanie do przysłowiowego zwrotu „ostatni z Siekierzyńskich”, wywodzącego się od tytułu powieści Józefa Ignacego Kraszewskiego.

${ }^{77}$ W końcu czerwca 1922 roku Tadeusz Żeleński (Boy) przeniósł się z Krakowa do Warszawy.

${ }^{48}$ Por. przypis 22.

${ }^{19}$ Por. listy 2 i 6.

${ }^{50}$ Dr Eugeniusz Artwiński, neurolog i psychiatra, prymariusz szpitala Św. Łazarza w Krakowie, później profesor Uniwersytetu Jana Kazimierza we Lwowie. Leczył wówczas Lechonia. 
Biały, gładki papier listowy. Arkusz złożony na pół, format tak uzyskanej karty 201 x $145 \mathrm{~mm}$. Tekst na s. 1ـ froletowym atramentem, dość czytelnie, choć ze skreśleniami (niektóre z nich zamazane do nieczytelności).

\section{1.}

Szanowny i Drogi Panie!

[Warszawa, 1924?, jesień?

Nie wiem, kiedy bym mógł wręczyć Panu osobiście książkę ${ }^{51}$, którą pozwalam sobie zło żyć Mu z wdzięcznością [i] największym zawsze podziwem; myślę więc, że będzie najlepie . zostawić ją w księgarni — może w ten sposób szybciej Pana dojdzie.

Bardzo pięknie rączki całuję Pani Hani i Mumci, wyrazy głębokiego szacunku łączę dl: Pana i życzenia, żeby się Panu nasze powietrze nie dawało we znaki ${ }^{52}$.

Jan Lechor

Mały kartonik formatu biletu wizytowego $(50 \times 112 \mathrm{~mm})$. Tekst jednostronnie, bardzo drobno, trudn czytelnie, czarnym atramentem. Kilka skreśleń i poprawek.

\section{2.}

[Warszawa, listopad-grudzień 1924 lub później] Czwartek

Wielce Szanowny i Drogi Panie!

Dzisiaj po południu - koło piątej będzie u mnie na herbacie kilku szczerze Panc uwielbiających panów z obu pokoleń rozmaitych sztuk pięknych. Gdyby Pan był tak dobr i nie liczył mi tego, że dotąd nie zameldowałem się u Niego na Zamku ${ }^{53}$ — a poza tym chcia: nam ofiarować jakieś dwie godzinki — bylibyśmy prawdziwie zaszczyceni i głęboko wdzięczni. Przepraszam, że dopiero teraz piszę - ale to w ostatniej chwili wynikło. Jeszcze raz najpiękniej Pana proszę i łączę ucałowania rączek dla Pań, a dla Pana wyrazy niezmiennegc oddania i czci.

\section{Lechón}

Cienki, biały papier listowy w linię, ze znakiem wodnym. Arkusz złożony na pół, format tak utworzonej karty $210 \times 128 \mathrm{~mm}$. Tekst na s. 1, czytelnie, czarnym atramentem.

\footnotetext{
${ }^{51}$ Prawdopodobnie chodzi o tomik Lechonia Srebrne i czarne, który ukazal się jesienią 1924 roku. Na tym opiera się hipotetyczne datowanie bileciku.

52 Lato 1924 roku Żeromscy spędzali na Helu. Liścik Lechonia pisany jest najwidoczniej tuż po ich powrocie do Konstancina.

${ }^{53}$ Żeromski zamieszkal na Zamku w listopadzie 1924 roku. Na tym opiera się datowanie listu.
} 
13.

Wronczyn ${ }^{54}, 12$ stycznia - [1925].

Szanowny i Drogi Panie! Ponieważ, jak to sobie obiecywałem — w ciszy i największym spokoju, na ślicznej wsi prapolskiej z pochodzenia, szczeropolskiej w tym, co i kto z niej zrobil - przeczytałem Pana piękne, mlode, pelne wiary i mądrej miłości Przedwiośnie niech mi Pan pozwoli jak dawniej skierować do Niego - tych parę słów serdecznego podziękowania i prawdziwego oddania. Jest tu pejzaż jak z Balladyny - nie tylko jeziora widziały początek Polski, ale i rozmaite budowle pamiętają Grunwald, a stare chrzcielnice jeszcze bardzo niepewne chrześcijaństwo. - Pogoda fatalna, ale jak mówi stary dowcip Kostrzewskiego lepsza taka niż żadna, a tak właśnie myślę o Warszawie. Inna rzecz, że nie umieć grać w mah-jonga ${ }^{55}$ na wsi — znaczy w zimie to samo, co latem nie jeździć konno. Pani Żeromskiej pięknie rączki całuję i Mumci, której się serdecznie przypominam, wyrazy głębokiego szacunku i najserdeczniejsze łączę dla Pana

$$
\begin{array}{r}
\text { sługa } \\
\text { Jan Lechoń }
\end{array}
$$

Karta pocztowa formatu $89 \times 137 \mathrm{~mm}$ (zachowana bez znaczka pocztowego). Tekst czarnym atramentem, drobno, ale dość czytelnie. Na odwrocie adres: Warszawa Zamek/ Królewski / JWielmożny Pan / Stefan Żeromski. - Tamże adres zwrotny: Wronczyn, st[acja] poczt[owa] Pobiedziska / woj. poznańskie / Jan Lechoń / u JWPP lackowskich.

14.

Pobiedziska, 22 I 1925

żeromski zamek warszawa

najserdeczniejsze powinszowania ${ }^{56}$ od oddanego

lechonia

Blankiet telegraficzny z naklejonym tekstem dalekopisu. Nadany w Pobiedziskach, przyjęty w Warszawie 22 stycznia.

${ }^{5+}$ Wronczyn - to posiadłość dyplomaty Tadeusza Jackowskiego i jego żony Anny (primo voto Jerzowej Leszczyńskiej), zaprzyjaźnionej blisko z Lechoniem. Majątek położony byl na linii Poznań-Gniezno, w pobliżu miasteczka Pobiedziska. Lechoń bywał w nim częstym gościem.

${ }^{s 5}$ Mah-jong (wym. madżong) - modna wówczas gra towarzyska pochodzenia chińskiego, rozgrywana na stoliku przez cztery osoby, a polegająca na kompletowaniu według określonych reguł specjalnie znakowanych kamieni, dobieranych z puli.

${ }^{56}$ Powinszowania dotyczyły przyznania Żeromskiemu nagrody literackiej Ministerstwa Wyznań Religijnych i Oświecenia Publicznego za Wiatr od morza. „Kurier Warszawski” podał wiadomość o nagrodzie w dodatku porannym do numeru $21 \mathrm{z} \mathrm{dn} .21$ stycznia. 
15.

[Florencja ${ }^{57}, 12$ IX 1925

Czcigodnego i Bardzo Drogiego Pana najserdeczniejszymi powinszowaniami ${ }^{58}$ i życze. niami zdrowia pozdrawiam z Florencji, gdzie często o Nim myślę. W czasie Pana choroby — niech Pan wierzy - dalecy Panu i nieznani z największą troską i najbliższą myśleli o Nim cóż dopiero ci, którzy w tych czasach - najjaśniej widzą najwspanialsze Pana dla narodı znaczenie i ci, którzy mają szczęście znać codzienną Pana szlachetność. Proszę wierzy، w oddanie sercem i przyjąć wyrazy najgłębszej czci, dla Pań ucałowanie rączek od

Jana Lechoni:

Widokówka (formatu $86 \times 135 \mathrm{~mm}$ ) z reprodukcją rzeźby przedstawiającej głowę Dantego. Tekst czar. nym atramentem, trudno czytelny. Datownik wyraźny: FIRENZE 12 IX 1925 FERROVIA. Adres: Polonia JWielmożny Pan / Stefan Żeromski / przez lask[awe] pośrednictwo / Księgarni „Tow[arzystwa] Wydawniczego” Mazowiecka 12/Warszawa.

${ }^{57} \mathrm{~W}$ roku 1925 Lechoń odbył mniej więcej trzytygodniową podróż do Włoch. We Florencji był od $10 \mathrm{dc}$ ok. 20 września.

${ }^{58}$ Powód powinszowań niewiadomy. Może spóźnione życzenia imieninowe, należne Żeromskiemu w dniu 2 września? 